\title{
水素科学の最前線 新学術領域研究「ハイドロジェハクス」の挑戦
}

\section{高速・局所移動水素と電子とのカップリングによる 新発想デバイスの設計}

1. はじめに：「高速 ·局所移動水素と電子とのカッ プリングによる新発想デバイスの設計」の概要

本稿では, 新学術領域研究「ハイドロジェノミクス」の A03-2 計画研究を中心に, 紹介させていただく. 本計画で は, 水素が「高速移動し, 電子とカップリング(協奏)する機 能」を高めるための高速移動化抢よびカップリング技術を創 出し, 他の水素機能と融合することで従来にはない新発想デ バイス設計を確立するとともに, 物質系(有機系, 無機系, 生体系)を超えた統一的な水素と電子のカップリングの学理 を構築することを目的としている(1)-(12). これらの研究を通 じて領域連携全体で連携して, 変幻自在な水素の性質を人類 が “使いこなす”ための指導原理となる新たな水素科学 (=ハイドロジェノミクス)の構築に貢献する事が研究のゴー ルである。

最近, 従来の延長線上にない水素科学の萌芽が注目されて いる. この萌芽の本質は複数の水素機能の相乗効果による “高次水素機能” の誘起であり，これにより個別の水素機能 だけでは実現困難な革新的材料・デバイス・反応プロセスの 創成が期待される. 実際に多彩な高次水素機能を誘起するた めには，学問分野の枠を超えて有機的に連携した新たな視点 の水素科学が必要となる.

例えば, 水素が有機, 無機, 生体材料などの様々な物質系 を多様な電荷 (プロトン $\mathrm{H}^{+}$, ヒドリド $\mathrm{H}^{-}$, およびその中間 の状態)で「高速移動」する機能と, ヒドリドとプロトンの 間の電荷移動, 即ち電荷を $-1 \sim+1$ の間で制御することよ って「反応プロセスを促進」する機能を効果的に融合するこ とで, 高効率物質変換, エネルギー貯蔵, 物性制御などの高 次水素機能が創出できる. さらに, この水素を, 水素と電子
のカップリング(協奏) (図 1(a)) という観点で統一的に捉え ることで, 物質系を越えた包括的な学理の構築することがで きる，さらにその原理に基づき，物質内，拈よび異相界面で 機能を発現・制御できる新発想デバイスを創出することも可 能となる.

A03-2 計画班は，有機系，無機系，生体系物質を対象と して, 水素と電子のカップリングによる機能創出, 新発想デ バイス設計，および学理構築を目指している.

小林玄器准教授 (分子科学研究所) は, 無機系ヒドリド伝導 体に注目している。 $\mathrm{La}_{2-x-y} \mathrm{Sr}_{x+y} \mathrm{LiH}_{1-x}+\mathrm{yO}_{3-y}$ (図 1 (c) ) (11), さらに最近は, 相転移によりヒドリド超イオン伝 導性を発現し, 高温相では伝導率が $10^{-2} \mathrm{Scm}^{-1}$ を越えると ドリド伝導体を見出している. 開発したヒドリド伝導体とヒ ドリド・電子混合伝導体を積層し, ヒドリド化学反応デバイ ス(ヒドリドリアクターデバイス)を他の班と協力しながら作 製中である.

また，樋口芳樹教授(兵庫県立大学) は, 生体系カップリン グシステムとしてヒドロゲナーゼ(図 1(d))を選択し，それ が示す 3 種類の酵素反応 (核スピン変換反応, 水素同位体交 換反応抢よび水素分解反応) についてラマン分光法を用いて 同時測定することに成功している(12)。これを用いて, 系を 乱すこと無く触媒反応を追跡する手法を確立することを目指 している.

そして, 筆者は, 有機系システムとして, 水素と電子のカ ップリングにより新機能を創出する分子性物質の開発, 機構 解明による学理構築, そしてその機構を利用した新発想デバ イス化を推進中である、本稿では, 新カップリング物質とし てベイポクロミック金属錯体 ${ }^{(1)}$, 抢よび水素移動により電気 伝導性と磁性がスイッチングする有機物質 ${ }^{(3)-(8)}$ (図 1(b))の 開発と, その自己集積型 2 分子層膜デバイスへの展開 ${ }^{(9)}(10)$

* 東京大学物性研究所; 教授, 所長 (

Design of Innovative Devices by Coupling High-Speed, Locally Mobile Hydrogen with Electrons; Hatsumi Mori (The Institute for Solid State Physics, The University of Tokyo, Kashiwa)

Keywords: hydrogen, hydrogenomics, higher-order hydrogen functions, hydrogen-electron coupling, design of innovative devices 2020年11月 4 日受理[doi:10.2320/materia.60.165] 

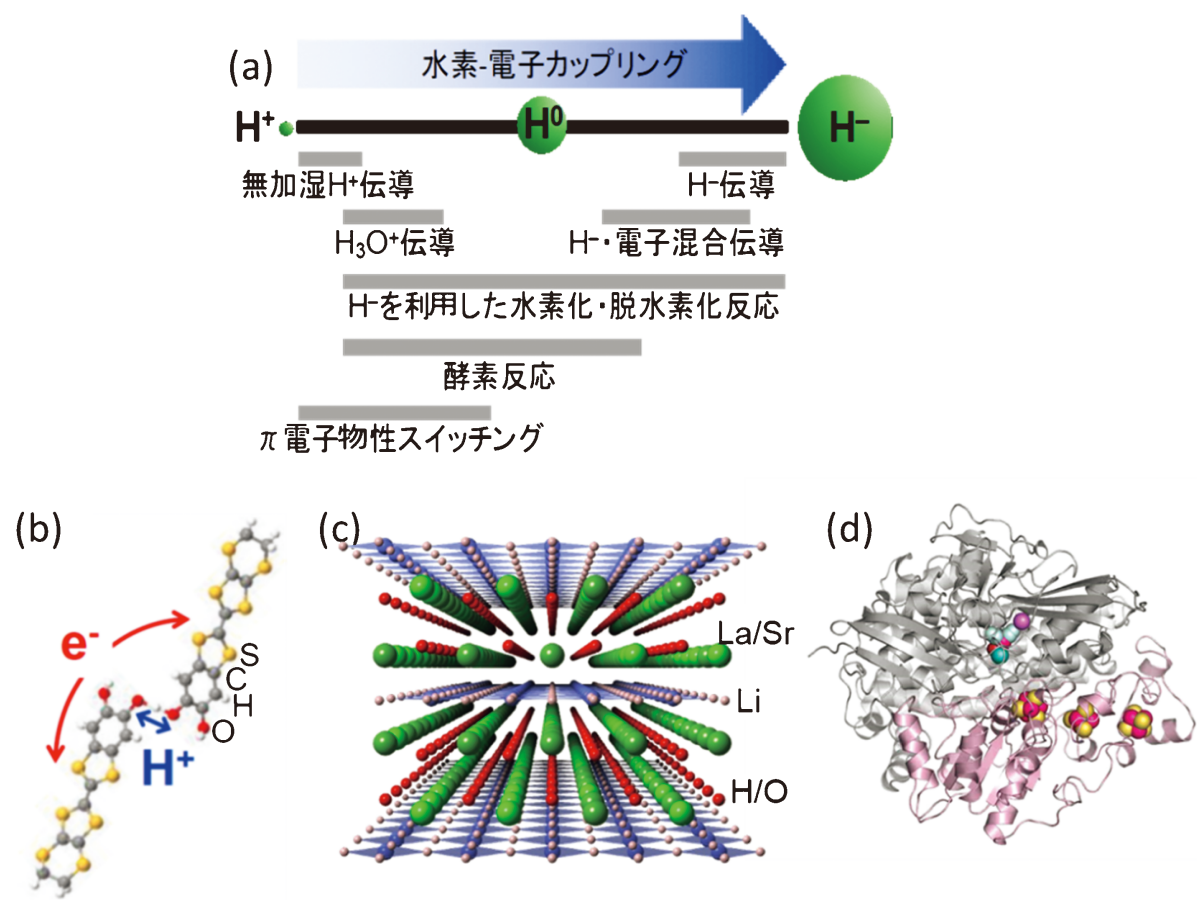

図 1 （a）水素-電子カップリングと各水素機能. カップリング機能を軸に，水素機能を複合化した新発想デバイス設計を確立す るとともに，物質系を超えた統一的な水素一電子カップリングの学理を構築する. 対象物質は, 水素一電子カップリング 型 (b) 有機伝導体 $\kappa-\mathrm{H}_{3}(\mathrm{Cat}-\mathrm{EDT}-\mathrm{TTF})_{2}{ }^{(3)-(8)}$ ，(c) 無機ヒドリド伝導体 $\mathrm{La}_{2-x-y} \mathrm{Sr}_{x+y} \mathrm{LiH}_{1-x}+\mathrm{yO}_{3-y}{ }^{(11)}$, (d) 生体系物質 [NiFe]-ヒドロゲナーゼ等(赤色と紫色原子：鉄, 黄色原子 : 硫黄, 青色原子 : ニッケル)(12)である.（オンラインカラー)

を紹介する。

\section{2. 水素と電子のカップリングによるベイポクロミズ 么金属錯体の開発 ${ }^{(1)}$}

蒸気に曝すことで色が变化するべイポクロミック物質は, その変化を視覚的に観測できることから有用な化学センサー のための候補物質として盛んに物質開発が行われている．新 規ベイポクロミック物質のさらなる開発と機能性制御および その設計指針の確立のためには，その蒸気応答メカニズムの 詳細な理解が非常に重要である。これまでメカニズムについ ては蒸気分子吸着に伴う分子構造変化に由来する金属錯体の $\mathrm{d}$ 軌道エネルギー変化や, 有機分子のフロンティア軌道間遷 移エネルギー変化などが提案されてきた，一方，我々は水素 結合によって $\pi$-d 電子状態を変調する戦略として水素結合 性金属ジチオレン錯体を基盤とした物質開発を行ってきた中 で，今回，新規 $\mathrm{Zn}$ ジチオレン錯体結晶 $\left(\mathrm{Ph}_{4} \mathrm{P}\right)_{2}[\mathrm{Zn}(4-$ mxbdt $\left.)_{2}\right]$ (1, 図 2,4-mxbdt $=4$-methoxybenzenedithiolate)を合成し，その水及びメタノール蒸気に対するべイポ クロミック特性による色変化抢よび蛍光色変化を見出すこと に成功した(図 2).

単結晶 X線構造解析の結果，水およびメタノールを吸着 した結晶の組成はそれぞれ $1 \cdot \mathrm{H}_{2} \mathrm{O}$ および $1 \cdot 2 \mathrm{MeOH}$ であっ た。また，それぞれの微結晶粉末の可視光吸収・発光スペク トル測定から, 視覚的な色变化 (吸収 : 橙 $\rightarrow$ 黄, 発光 : 赤 $\rightarrow$ 黄橙) と一致するブルーシフトが観測された。このベイポク
ロミズムのメカニズムを明らかにするために，蒸気吸着前後 の結晶構造を比較した。蒸気吸着後の結晶において，水・メ タノール分子のいずれも $\mathrm{Zn}$ 錯体の硫黄原子との間に $\mathrm{O}-\mathrm{H} \cdots$ $\mathrm{S}$ 型の水素結合を形成していた。一方, $\mathrm{Zn}$ 錯体の分子構 造・配列は $\mathbf{1} \cdot \mathrm{H}_{2} \mathbf{O}$ ではほとんど変化しておらず， 1 . $2 \mathrm{MeOH}$ では有意に変化していた．したがって，従来の多く のベイポクロミック物質で議論されてきたような $\mathrm{Zn}$ 錯体の 分子 ·結晶構造変化ではなく, $\mathrm{Zn}$ 錯体と蒸気分子との水素 結合形成が本結晶のベイポクロミズムと本質的に関係してい ることが示唆された。そこで，実験的に得られた結晶構造を 基に DFT 計算を行い，結晶軌道エネルギーと吸収スペクト ルを見積もった，その結果，溶媒分子を含む結晶の可視光吸 収に該当する結晶軌道間遷移エネルギーは増加しており，そ れに応じて，計算された吸収スペクトルもブルーシフトして いた。ささらに Mulliken 電荷分布解析と結晶軌道概形の比較 から， $1 \cdot \mathrm{H}_{2} \mathrm{O}$ 抢よび $1 \cdot 2 \mathrm{MeOH}$ では分子間水素結合形成に よって Zn 錯体の HOMO/LUMO と蒸気分子の LUMO が混 成し, $\mathrm{Zn}$ 錯体加蒸気分子に電子移動 $\left(\mathrm{H}_{2} \mathrm{O}: 0.19 ; \mathrm{MeOH}\right.$ : 0.23-0.26 electrons/molecule)が起こっていることが示唆さ れた。これが占有/非占有結晶軌道エネルギーに非対称な安 定化度合いをもたらすことでブルーシフトを示すことが明ら かになった．以上の結果から，本結晶に打るべイポクロミ ズム (色変化, 蛍光色変化) が水素結合形成に伴う電子移動と いう新しいメカニズムによるものであることを明らかにした。 


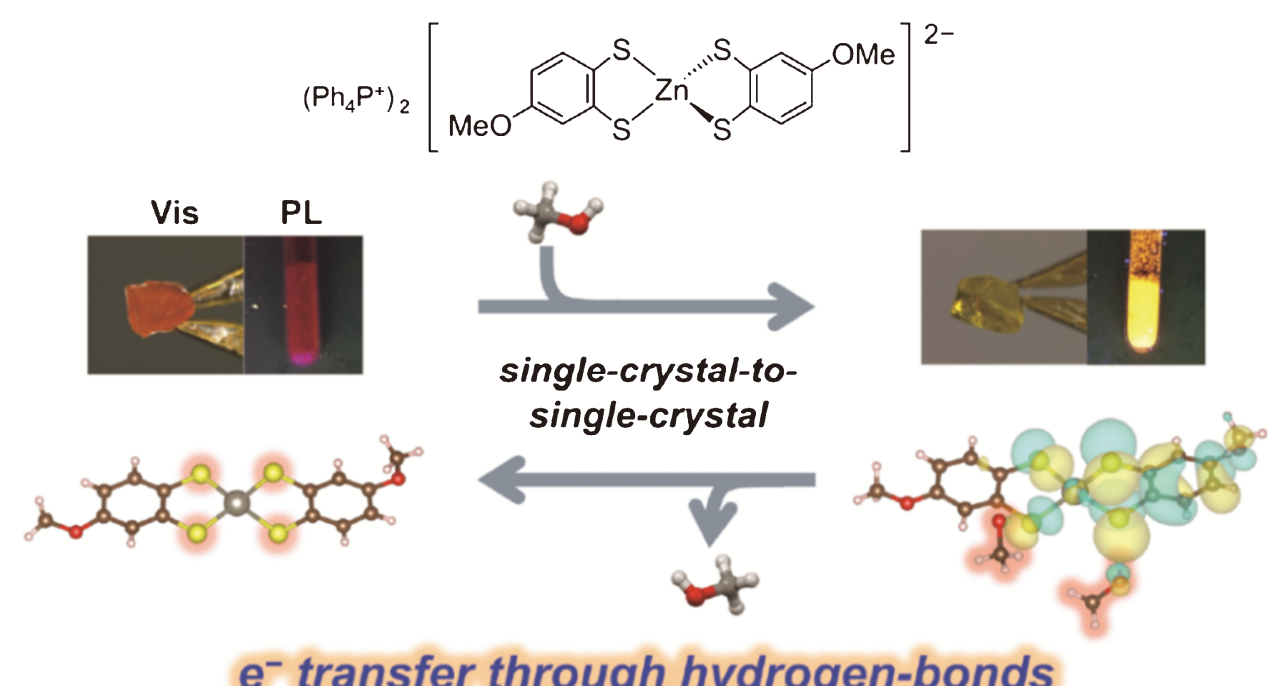

transfer through hydrogen-bonds

図 2 亜鉛ジチオレン金属錯体結晶において，分子間電子移動と水素結合形成が結合した新規な水素一電子カップリング型ベイ ポクロミズム機構を見出した ${ }^{(1)}$.メタノール蒸気にさらすことによりオレンジから黄色への色変化, 蛍光色変化が観測さ れた。(オンラインカラー)

3. 高速·局所移動水素と電子とのカップリングによ り電気伝導性と磁性がスイッチングする有機伝導 体の開発と二分子膜デバイスへの応用 ${ }^{(3)-(10)}$

近年我々は, 水素のダイナミクスと $\pi$ 電子とがカップル した $\pi$ 電子一水素相関型分子性物質の開発, その機能物性 開拓, 抢よびその新発想デバイス化を行っている，この系で は, 水素の熱摇らぎ, 無秩序一秩序化, あるいは量子摇らぎ 等の動的変化が $\pi$ 電子の動きとカップルして, $\pi$ 電子系の量 子スピン摇らぎや, 電荷不均化による電荷秩序相転移を引き 起こしている.ささらに, この $\pi$ 電子一水素相関系に外場々 して電場, 圧力を印可すると, 水素抢よび $\pi$ 電子系が応答 し, 巨大非線形伝導, 電場誘起スイッチング(7), 圧力誘起又 イッチングとして常磁性一非磁性転移 ${ }^{(8)}$, 超伝導転移が出現 することが見いだされている，本稿では，その新カップリン グ機能(3)-(8) およよ゙新発想デバイス ${ }^{(9)(10)}$ について紹介する.

水素一 $\pi$ 電子相関系の $\kappa-\mathrm{H}_{3}(\mathrm{Cat}-\mathrm{EDT}-\mathrm{TTF})_{2}(\kappa-\mathrm{TTF}$ と 略する)では, 2 次元伝導層内で, 二量化した分子が三角格 子を形成してダイマーモット状態となっている.さらに，こ の 2 次元層は, -1 価の水素結合 $[\mathrm{O} . . \mathrm{H} . . \mathrm{O}]^{-1}$ で連結されて 抢り, 通常のようにアニオン層を持たず, 単一水素結合ユニ ットからの及構成されている大変珍しい系である. この水素 結合は, 室温から少なくとも $50 \mathrm{mK}$ の低温まで対称性を保 っており, 量子化学計算や誘電応答の実験より, 水素結合中 のプロトンは, 高温では熱摇らぎ, 低温では量子摇らぎが効 き,プロトンの動きと $\pi$ 電子系が相関して, 基底状態は量 子スピン液体状態(4)(6)であることが, 静磁化率, トルク ${ }^{(4)}$, 比熱, 熱伝導と誘電応答 ${ }^{(6)},{ }^{13} \mathrm{C}-\mathrm{NMR}$ からも確かめられて いる. 一方, その重水素同位体である $\kappa-\mathrm{D}_{3}$ (Cat-EDT$\mathrm{TTF})_{2}(\kappa-\mathrm{D}-\mathrm{TTF}$ と略する $)$ でも, 2 次元伝導層が -1 価の 水素結合 $[\mathrm{O} . . \mathrm{D} . . . \mathrm{O}]^{-1}$ で連結され, 高温では, $\kappa$-TTF とほ
ぼ同じ振る舞いを示すが, $185 \mathrm{~K}$ 以下で, 半導体一絶縁体, 抢よび常磁性一非磁性転移を起こす。結晶構造解析によると, $185 \mathrm{~K}$ で水素結合が， [O...D-O $]^{-1}$ と非対称的に秩序化する ことにより, 水素結合ユニット内で電荷移動が起こって電子 系が電荷不均化し, 電荷秩序化による相転移が起こることが 明らかとなっている(5).このように水素結合内のプロトンの 電荷を制御することにより， $\pi$ 電子物性が大きく変化する振 る舞いがみられる。

さらに，基底状態が量子スピン液体状態である $\kappa$-TTFに 外場として圧力を印可したところ, 分子間相互作用が増大し て抵抗は減少するが, 水素を起源として, 大変珍しい圧力誘 起絶縁化転移が観測された ${ }^{(8)}$. 一方, 類縁体である Se 化合 物 $\left[\kappa-\mathrm{H}_{3}(\mathrm{Cat}-\mathrm{EDT}-\mathrm{ST})_{2}\right]$ では, バンド幅の増大により, $\pi$ 電子系が安定化し, 常圧下では $\mathrm{S}$ 体同様, 量子スピン液体 であるが，加圧すると約 $3 \mathrm{~K}$ で超伝導転移が観測された。 量子スピン液体相と反強誘電体相の境界である超臨界相に位 置する超伝導について, 水素の摇らぎがぞのように反映して いるのかが興味深く, 現在研究進行中である.

さらに, この水素一 $\pi$ 電子カップリング有機伝導体をの 自己集積型 2 分子層膜の作製に成功して抢り, 今後, プロ トンスイッチング新発想デバイスの創成が期待されている (図3).

\section{4. まと め}

A03-2 班では, 有機系, 無機系, 生体系に抢いて, 高 速・局所移動する水素と電子がカップリングすることによる 新機能の開発, その機構の解明を行っている, さらに, 高密 度化, 界面局在・高活性化などの機能を極めた他の班と連携 をしながら, 新発想デバイスの設計, 創出とその学理の構築 を目指した水素科学を推進している.

その中で, 本領域では, 水素原子, 分子, プロトンやヒド 


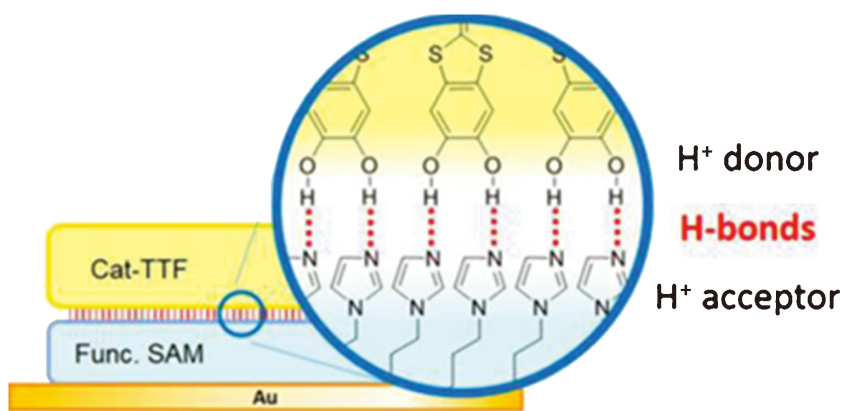

図 3 自己集積型 2 分子層膜に抢けるプロトンスイッチング デバイス ${ }^{(9)(10)}$. (オンラインカラー)

リドイオンと変幻自在な水素が，幅広いタイムスケール，空 間スケールで刻々と変化し，機能を発現する様子を，最先端 の計測と計算で捉えられるところに特徵があると思う.

水素が, 周りの環境, 外場で, ぞのように変幻自在に状態 を変え機能を発現するのか. 水素と, 電子(電荷, スピン, 軌道, 格子), 光子, 電場, 磁場などとのカップリングおよ び摂動という観点で統一的な学理を構築し, 機能発現と制御 に繋がれば素晴らしい。

次世代エネルギー, 資源, 環境課題解決に打いて, 水素基 盤科学研究は急務であり, 今後も新学術領域内外の連携を生 かしてハイドロジェノミクスの構築に邁進したい.

\section{文献}

(1) S. Yokomori, S. Dekura, T. Fujino, M. Kawamura, T. Ozaki and H. Mori: J. Mater. Chem. C, in press (2020).

( 2 ) Y. Sunairi, S. Dekura, A. Ueda, T. Ida, M. Mizuno and H. Mori: J. Phys. Soc. Jpn., 89(2020), 051008.

( 3 ) T. Isono, H. Kamo, A. Ueda, K. Takahashi, A. Nakao, R. Kumai, H. Nakao, K. Kobayashi, Y. Murakami and H. Mori:

Nature Commun., 4(2013), 1344.

(4) T. Isono, H. Kamo, A. Ueda, K. Takahashi, M. Kimata, H. Tajima, S. Tsuchiya, T. Terashima, S. Uji and H. Mori: Phys. Rev. Lett., 112 (2014), 177201.

( 5 ) A. Ueda, S. Yamada, T. Isono, H. Kamo, A. Nakao, R. Kumai, H. Nakao, Y. Murakami, K. Yamamoto, Y. Nishio and H. Mori: J. Am. Chem. Soc., 136(2014), 12184-12192.

(6) M. Shimozawa, K. Hashimoto, A. Ueda, Y. Suzuki, K. Sugii, S. Yamada, Y. Imai, R. Kobayashi, K. Itoh, S. Iguchi, M. Naka, S. Ishihara, H. Mori, T. Sasaki and M. Yamashita: Nat. Commun., 8 (2017), 1821.

( 7 ) A. Ueda, K. Kishimoto, Y. Sunairi, J. Yoshida, H. Yamakawa, T. Miyamoto, T. Terashige, H. Okamoto and H. Mori: J. Phys. Soc. Jpn., 88 (2019), 034710.

( 8 ) A. Ueda, K. Kishimoto, T. Isono, S. Yamada, H. Kamo, K. Kobayashi, R. Kumai, Y. Murakami, J. Gouchi, Y. Uwatoko, Y. Nishio and H. Mori: RSC Adv., 9(2019), 18353-18358.

( 9 ) Y. Kanematsu, H. S. Kato, S. Yoshimoto, A. Ueda, S. Yamamoto, H. Mori, J. Yoshinobu, I. Matsuda and M. Tachikawa: Chem. Phys. Lett., 741 (2020), 137091.

(10) H. S. Kato, S. Yoshimoto, A. Ueda, S. Yamamoto, Y. Kanematsu, M. Tachikawa, H. Mori, J. Yoshinobu and I. Matsuda: Langmuir, 34 (2018), 2189-2197.

(11) G. Kobayashi, Y. Hinuma, S. Matsuoka, A. Watanabe, M Iqbal, M. Hirayama, M. Yonemura, T. Kamiyama, I. Tanaka and R. Kanno: Science, 351(2016), 1314-1317.

(12) Y. K. Nakagawa, K. Nishikawa, S. Nakashima, S. Inoue, T. Ohta, T. Ogura, Y. Shigeta, K. Fukutani, T. Yagi and Y. Higuchi: Protein Sci., 28(2019), 663-670.

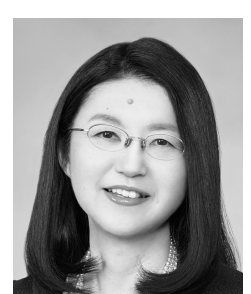

森 初果

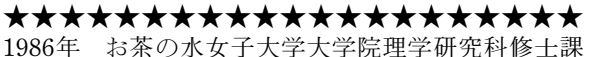
1986年 抢茶の水女子大学大学院理学研究科修士課 程修了

主な略歴

1989年 4 月 超電導工学研究所研究員

2001年 4 月 東京大学物性研究所助教授

2010年 4 月- 現職

専門分野：分子性機能物質科学

(○分子性機能物質およびシステムの開発と機能物性研 究に従事. 分子性の電子/プロトン伝導体, 磁性 体，誘電体，発光・蛍光物質等や有機トランジスタ の開発と機能物性研究を中心に活動.

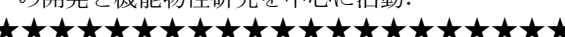

